\title{
On Hunger and Child Mortality in India
}

\author{
Raghav Gaiha \\ Centre for Population and Development Studies, Harvard University, MA, USA and Faculty \\ of Management Studies, University of Delhi. India \\ Vani S. Kulkarni \\ Department of Sociology, Harvard University, MA, USA \\ Manoj K. Pandey \\ Institute of Economic Growth, Delhi, India \\ Katsushi S. Imai ${ }^{1}$ \\ Economics, School of Social Sciences, University of Manchester, UK
}

4 May 2009

\begin{abstract}
Despite accelerated growth there is pervasive hunger, child undernutrition and mortality. Our analysis focuses on their determinants. Raising living standards alone will not reduce hunger and undernutrition. Reduction of rural/urban disparities, income inequality, consumer price stabilisation, mothers' literacy have all roles of varying importance in different nutrition indicators. Somewhat surprisingly, PDS does not have a significant effect on any of them. Generally, child undernutrition and mortality rise with poverty. Our analysis confirms that media exposure triggers public action, and helps avert child undernutrition and mortality. Drastic reduction of economic inequality is in fact key to averting child mortality.
\end{abstract}

Keywords: Hunger, underweight, child mortality, prices, inequality, literacy, India JEL Codes: I10, I31, I32

\footnotetext{
${ }^{1}$ Corresponding Author: Dr Katsushi S. Imai, Economics, School of Social Sciences, University of Manchester, Arthur Lewis Building, Oxford Road, Manchester M13 9PL, UK; Telephone: +44-(0)161-275-4827, Fax: +44-(0)161-275-4812 Email:

Katsushi.Imai@manchester.ac.uk.
} 


\section{On Hunger and Child Mortality in India ${ }^{*}$}

\section{Introduction}

India has recorded an unprecedented growth in recent years-in fact; it is regarded as one of the fastest growing economies in the world. Real gross domestic product (GDP) per capita grew at 3.95 per cent annually during 1980-2005, and at 5.4 per cent annually from 2000 to 2005. Real per capita consumption growth also accelerated-from 2.2 per cent a year in the 1980s, at 2.5 per cent a year in the 1990s, and at 3.9 per cent a year from 2000 to 2005. Although household surveys register slower growth rates of consumption, there has been a significant reduction in poverty since the early 1980s (Deaton and Dreze, 2002, Jha et al., 2009 a, and Himanshu, 2007, Gaiha et al. 2008). Yet per capita calorie intake has declined, as also of many other nutrients. In fact, as noted in Deaton and Dreze, 2008, more than three quarters of the population live in households whose per capita calorie intake is less than 2,100 in urban areas and 2400 in rural areas-calorie intakes regarded as 'minimum requirements' in India. $^{2}$ A related concern is that anthropometric indicators tell an equally dismal story. Some of these indicators are the worst in the world. Besides, improvements in these indicators are sluggish despite impressive economic growth. Indeed, according to the National Family Health Survey (NFHS hereafter), the proportion of underweight children remained virtually unchanged between 1998-99 and 2005-06-from 47 to 46 per cent for the age-group 0-3 years (Deaton and Dreze, 2008). ${ }^{3}$

A fascinating new study (Menon et al. 2009) draws an equally gloomy picture. Although serious doubts remain about the appropriateness of the Global Hunger Index (GHI) constructed by the International Food Policy Research Institute (IFPRI) researchers (e.g. aggregation of three indicators-inadequate consumption, child underweight, and child mortality is deeply problematic), its application to 17 major Indian states is of considerable

\footnotetext{
* We are grateful to Raghbendra Jha and Varsha S. Kulkarni for useful discussions. The views expressed are, however, personal and not necessarily of the institutions to which they are affiliated.

${ }^{2}$ Deaton and Dreze, 2008, draw attention to a downward shift of the "calorie Engel curve" that plots calorie consumption against per capita household expenditure: calorie consumption at a given level of per capita expenditure has steadily declined over the last 20 years. Why this should happen in a country as poor and malnourished as India is intriguing. For a conjecture, see Deaton and Dreze, 2008.

${ }^{3}$ Deaton and Dreze, 2008, are emphatic “ Undernutrition levels in India remain higher even than for most countries of sub-Saharan Africa, even though those countries are much poorer than India, have grown much more slowly, and have much higher levels of infant and child mortality”, (p.2).
} 
interest. ${ }^{4}$ This analysis is based on the third round of the NFHS (2005-06)-hereafter referred to as NFHS-III data-and the $61^{\text {st }}$ round of the NSS data for 2004-05.

Contrary to the views of the authors, the severity of hunger is better reflected in the individual components than in the State Hunger Index. Using the calorie undernutrition measure-based on a calorie cutoff of 1632 kcals per person per day-the average works out to be 20 per cent. ${ }^{5,6}$ At least, three states were well above the average (viz. Tamil Nadu (29.1 per cent), Kerala (28.6 per cent), and Karnataka (28.1 per cent). The second componentproportion of underweight children <5years-was estimated at the state level using data from the NFHS-III data. This denotes the proportion of children in each state whose weight-for-age was less than two standard deviations below the WHO reference. The average for all-India is 42.5 per cent. ${ }^{7}$ Bihar (56.1 per cent), Jharkand (57.1 per cent) and Madhya Pradesh (59.8 per cent) were among the worst performers. The third indicator, under-five mortality rate (deaths per hundred), averaged 7.4, with Uttar Pradesh (9.6), Jharkand (9.3) and Madhya Pradesh (9.4) among those with the most dismal performance. ${ }^{8}$

The objective of the present study is to build on this important contribution, by analysing in greater detail the underlying determinants. Based on this analysis, it is hoped, some new light will be thrown on policy priorities.

\footnotetext{
${ }^{4}$ As noted by Menon et al. 2009, the GHI 2008 reveals India’s continued lacklustre performance at eradicating hunger: India ranks $66^{\text {th }}$ out of the 88 developing countries and countries in transition for which the index has been calculated.

${ }^{5}$ Note that typically higher calorie norms are used in the Indian context. Deaton and Dreze, 2008, for example, report that the share of population consuming less than 2400 kcals per day was 66.1 per cent in rural India in 2004-05, and the share consuming less than 2100 kcals per day in urban India was nearly 61 per cent. The allIndia average was thus as high as nearly 65 per cent of the population. That is, three times higher than that reported by Menon et al., 2009.

${ }^{6}$ In important contributions, Srinivasan ,1981, 1992, 1994, argues cogently against the usefulness of calorie norms . This concern is echoed by Deaton and Dreze, 2008. They emphasise that there are too many sources of variation in calorie-requirements for standard, time-invariant calorie norms to be usefully applied to large segments of the population.

${ }^{7}$ Deaton and Dreze, 2008, report the proportions of underweight children below three standard deviations of the WHO reference: these were 17.6 per cent in 1998-99 and 15.8 per cent in 2005-06. The stunting estimates were high too and recorded a slight reduction over this period: from 51 per cent to 44.9 per cent.

8 Deaton and Dreze, 2008, explore combining intake data with outcome focused indicators, such as anthropometric indicators. However, anthropometric measures have their own limitations. First, there are unresolved puzzles, such as high prevalence of stunting among affluent children. Secondly, there are inconsistencies between different sources of data (viz. National Family Health Survey and National Nutrition Monitoring Bureau). While broad long-term trends are reasonably clear, there is some inconsistency about recent changes (p.10).
} 
The rest of the paper is structured as follows. In Section II, we discuss the specifications for each nutritional indicator, followed by a discussion of the results in Section III. Finally, Section IV assesses these findings from a broad policy perspective.

\section{Specification}

Let us first consider the determinants of calorie intake. Algebraically, prevalence of calorieundernourishment is posited to depend on

$$
\log (\text { Calorie UnderNourishment })_{i}=\beta_{0}+\beta_{1} M \text { PCE } E_{i}+\beta_{2}(M P C E)_{i}{ }^{2}+\beta_{3} C P I A L_{i}+\beta_{4}(C P I A L)_{i}{ }^{2}+
$$$$
\beta_{5} \text { RatioRuraltoUrbanMPCE } E_{i}+\beta_{6} \text { BIMARU }+\varepsilon_{1 i}
$$

where the right side variables are monthly per capita expenditure (MPCE), its square, Consumer Price Index for Agricultural Labourers (CPIAL), its square, ratio of rural MPCE to urban MPCE, and whether a state belonged to the BIMARU group of states (Bihar, Madhya Pradesh, Rajasthan and Uttar Pradesh).

A brief justification for this specification is necessary. The (log) proportion of undernourished in the population is posited to vary with the monthly per capita expenditure as a proxy for income/ earnings. At given prices, the minimum calorie intake requires a certain income. As income rises, calorie intake is supposed to rise. However, at higher levels of income, other characteristics of food and variety take priority (e.g. packaging, flavour). ${ }^{9}$ Consequently, calorie intake may rise but at a decreasing rate. ${ }^{10}$ Arguably, the proportion of undernourished may also decrease with higher MPCE but at a diminishing rate. ${ }^{11}$ Given income, the higher the price of food, the lower would be the calorie intake and the higher would be the proportion of calorie-deficient population. As the prevalence of hunger is higher in rural areas, with fewer remunerative employment opportunities, more difficult access to markets, lower sanitation and hygiene standards, and less awareness of nutritional values, there may be an additional factor (i.e. rural/urban disparity) contributing to the overall

\footnotetext{
${ }^{9}$ See, for example, Jha et al. 2009 b, c,d,

${ }^{10}$ Here the focus is on undernutrition as a consequence of low income. While this relationship is confirmed, this is only part of the link between undernutrition and income, as there is another significant effect in which the causality is reversed under certain conditions (i.e,.undernutrition perpetuates poverty by limiting remunerative income earning prospects in an agrarian economy with efficiency wages and job rationing). This was first formalized in Dasgupta, 1993; for an admirable critique, see Srinivasan, 1994; and for an empirical validation, see Jha et al. 2009 b..

${ }^{11}$ A presumption here is that what is plausible for an individual is equally plausible for an aggregate of individuals.
} 
prevalence of hunger Above all, residing in any of the most backward states (the so called BIMARU states) may further add to hunger reflected in calorie deficiency. Briefly, apart from more limited earning prospects, less developed markets and harder access to them, the hardships for large segments of the populations are compounded by weak and corrupt governments that are less responsive to subsistence requirements. BIMARU as a dummy variable (it takes the value 1 if a state is BIMARU and 0 otherwise) is supposed to capture the fragility of subsistence living standards. i denotes state and $\varepsilon_{1 i}$ is independently, and identically distributed (i.i.d) error term.

The specification used for the second component of hunger, proportion of underweight children $<5$ years, is given in equation (2):

Log $(\text { Underweight Children })_{i}=\gamma_{0}+\gamma_{1}$ MPCE $_{i}+\gamma_{2}$ FemaleLiteracyRate $_{i}+\varepsilon_{2 i}$

where MPCE is again monthly per capita expenditure; female literacy rate of women in the reproductive age-group (15-49 years) approximates mother's literacy rate, and $\varepsilon_{2 i}$ is i.i.d. error term.

As undernutrition of children $<5$ years reflected in the measure used here is in part an outcome of economic deprivation, MPCE is used to capture this relationship. To the extent that feeding and nutritional care of children depend critically on the awareness levels of mothers-approximated by their literacy-this is posited to be a determinant of undernutrition of children $<5$ years. ${ }^{12}$

The third and an extreme indicator or outcome of acute undernutrition among children $<5$ years is child mortality (number of deaths among children $<5$ years who were born live).

\footnotetext{
12 This effect has been extensively documented. See, for example, Behrman and Deolalikar, 1989, Strauss and Thomas, 1998, and Bozzolli et al. 2007. For confirmation with Indian data, see Gaiha and Kulkarni (2005). For a lively critique of a biomedical approach to nutrition as part of a review of World Bank financed nutrition programme in Tamil Nadu, Tamil Nadu Integrated Nutrition Programme, see Sridhar, 2008. This critique rests on a somewhat rigid dichotomy between hunger as the outcome of choice (e.g. unhealthy nutrition practices) and an avoidable consequence of circumstances (e.g. poverty, unsatisfactory hygiene and sanitation standards, lack of access to basic medical amenities). Our uneasiness stems from the somewhat artificial separation as choice could also be conditioned on the circumstances (e.g,. a household is poor not just because someone made a wrong career/occupation choice but also because the village environment did not allow better choices).
} 
$\log (\text { ChildMortality })_{i}=\rho_{0}+\rho_{1}$ CPIAL $_{i}+\rho_{2} \Delta$ CPIAL $_{i}+\rho_{3}$ FemaleLiteracyRate $_{i}+\rho_{4} \hat{P D S}_{i}+$ $\rho_{5}$ UnderweightChildren $_{i}+\rho_{6}$ Gini $_{i}+\rho_{7}\left(\right.$ Gini $^{2}{ }_{i}+\varepsilon_{3 i}$

The specification retains CPIAL, $\triangle C P I A L$ and female literacy rate as explanatory variables and adds (IV) percentage PDS offtake and (IV) estimate of proportion of underweight children $<5$ years. ${ }^{13}$ The Gini and its square as explanatory variables are introduced to capture another dimension of deprivation in so far as higher inequality (at a given MPCE) implies a higher proportion of poor or those subsisting at low levels of income. ${ }^{14}$ The square of the Gini, if significant, implies a non-linear relationship with the dependent variable (in logs). As under-five mortality is an extreme outcome, there are likely to be thresholds of severe undernutrition over which mortality is highly likely. This was not feasible to check with the state-level data. Hence the specification used is no more than a first approximation. $\varepsilon_{3 i}$ is an i.i.d error term.

\section{Results}

(a) Determinants of Hunger and Mortality

Let us first consider the ordinary least squares (OLS) results on the prevalence of calorie deficiency presented in table 1.

Table 1

Determinants of Prevalence of Calorie Under-Nourishment (\%)

\begin{tabular}{|c|c|c|c|c|c|c|}
\hline \multirow[t]{2}{*}{ Source } & \multirow[t]{2}{*}{ SS } & \multirow[t]{2}{*}{$\mathrm{df}$} & \multirow{2}{*}{\multicolumn{2}{|c|}{ MS }} & \multicolumn{2}{|c|}{$\begin{array}{l}\text { Number of } \\
\text { Observations }=17 \\
\end{array}$} \\
\hline & & & & & \multicolumn{2}{|c|}{$\mathrm{F}(6,10)=0.46$} \\
\hline Model & 0.448 & 6 & & 75 & Prob $>F=$ & 215 \\
\hline \multirow[t]{2}{*}{ Residual } & \multirow[t]{2}{*}{1.616} & \multirow[t]{2}{*}{10} & \multirow{2}{*}{\multicolumn{2}{|c|}{0.162}} & \multicolumn{2}{|c|}{ R-squared $=0.2170$} \\
\hline & & & & & \multicolumn{2}{|c|}{ Adj R-squared $=-0.2528$} \\
\hline Total & 2.063 & 16 & \multicolumn{2}{|c|}{0.129} & Root MS & $=.40195$ \\
\hline $\begin{array}{l}\text { Log of Prevalence of calorie } \\
\text { under-nourishment (\%) }\end{array}$ & Coef. & Std. Err. & $\mathrm{t}$ & $\mathrm{P}>|\mathrm{t}|$ & \multicolumn{2}{|c|}{ [95\% Conf. Interval] } \\
\hline MPCE (Rs.) for year 2004-05 & -0.004 & 0.011 & $\begin{array}{c}- \\
0.35\end{array}$ & 0.736 & -0.029 & 0.021 \\
\hline Square of MPCE (Rs.) for & 3.71E-06 & 1.38E-05 & 0.27 & 0.793 & $-2.70 \mathrm{E}-$ & $3.44 \mathrm{E}-05$ \\
\hline
\end{tabular}

${ }^{13}$ The IV estimation of offtake from the PDS is shown in the Annex.

${ }^{14}$ Although we experimented with MPCE as an explanatory variable, its effect did not show up. However, as illustrated in Fig: 3, mortality and poverty are positively related. 


\begin{tabular}{|l|c|c|c|c|c|c|}
\hline year 2004-05 & & & & & 05 & \\
\hline CPIAL for the year 2004-05 & 0.292 & 0.466 & 0.63 & 0.544 & -0.745 & 1.330 \\
\hline $\begin{array}{l}\text { Square of CPIAL for the year } \\
\text { 2004-05 }\end{array}$ & $-4.20 \mathrm{E}-04$ & 0.001 & - & 0.546 & -0.002 & 0.001 \\
\hline $\begin{array}{l}\text { Ratio of Rural to Urban } \\
\text { MPCE for year 2004-05 }\end{array}$ & -0.425 & 2.297 & - & 0.857 & -5.5439 & 4.694275 \\
\hline Dummy for BIMARU States & -0.292 & 0.397 & - & 0.479 & -1.17604 & 0.592702 \\
\hline _cons & -50.766 & 80.640 & - & 0.543 & -230.444 & 128.9119 \\
\hline
\end{tabular}

Note: $\quad$ The Breusch-Pagan / Cook-Weisberg test is used to test for heteroscedasticity. The chi-square statistic with 6 degrees of freedom (9.97) and corresponding probability value (0.1261) suggest that the null hypothesis of constant variance is not rejected.

As it turns out, none of the explanatory variables possess significant coefficients. Although heteroscedasticity is not confirmed, the robust regression results are of considerable interest in themselves.

Table 2

Determinants of Prevalence of Calorie Under-Nourishment (\%) (Robust Regression)

\begin{tabular}{|c|c|c|c|c|c|c|}
\hline \multicolumn{5}{|l|}{ Robust Regression } & \multicolumn{2}{|c|}{$\begin{array}{l}\text { Number of Observations }=15 \\
F(6,8)=8.40\end{array}$} \\
\hline & & & & & \multicolumn{2}{|c|}{ Prob $>F=0.0042$} \\
\hline $\begin{array}{l}\text { Log of Prevalence of } \\
\text { calorie under- } \\
\text { nourishment (\%) }\end{array}$ & Coef. & Std. Err. & $\mathrm{t}$ & $\mathrm{P}>|\mathrm{t}|$ & {$[95 \%$} & Interval] \\
\hline $\begin{array}{l}\text { MPCE (Rs.) for year } \\
\text { 2004-05 }\end{array}$ & -0.079 & 0.018 & -4.31 & 0.003 & -0.122 & -0.037 \\
\hline $\begin{array}{l}\text { Square of MPCE (Rs.) } \\
\text { for year 2004-05 }\end{array}$ & $1.14 \mathrm{E}-04$ & $2.57 \mathrm{E}-05$ & 4.43 & 0.002 & $5.45 \mathrm{E}-05$ & 0.000173 \\
\hline $\begin{array}{l}\text { CPIAL for the year } \\
\text { 2004-05 }\end{array}$ & 0.685 & 0.343 & 2 & 0.081 & -0.106 & 1.475 \\
\hline $\begin{array}{l}\text { Square of CPIAL for } \\
\text { the year 2004-05 }\end{array}$ & -0.001 & 0.001 & -2.01 & 0.079 & -0.002 & 0.000 \\
\hline $\begin{array}{l}\text { Ratio of Rural to } \\
\text { Urban MPCE for year } \\
2004-05\end{array}$ & -7.330 & 1.181 & -6.21 & 0.000 & -10.054 & -4.607 \\
\hline $\begin{array}{l}\text { Dummy for BIMARU } \\
\text { States }\end{array}$ & 0.731 & 0.186 & 3.94 & 0.004 & 0.303 & 1.160 \\
\hline _cons & -100.036 & 55.779 & -1.79 & 0.111 & -228.663 & 28.591 \\
\hline
\end{tabular}

Table 2 suggests that proportions of calorie-undernourished vary inversely with MPCE, implying lower proportions in states with higher MPCE. However, the square of MPCE has a significant positive coefficient that implies a weakening of the inverse relationship at higher MPCE. But the magnitude of the coefficient of the square of MPCE is relatively small. This suggests that, given low MPCEs, the inverse relationship is likely to dominate for small 
increments in MPCEs. As expected, the higher the CPIAL, the greater is the prevalence of calorie-deficiency. However, given the negative coefficient of (CPIAL) ${ }^{2}$, the positive effect of CPIAL diminishes at higher values. This is presumably a result of substitution of cheaper sources of calorie. ${ }^{15}$ As hypothesised, the lower the disparity between rural and urban MPCE, the lower is the proportion of calorie-deficient population. This points to greater payoff to raising living standards in rural areas, relatively to the urban. Somewhat surprisingly, in other specifications, offtake of PDS does not have a significant negative effect. ${ }^{16}$

Controlling for all these effects, if a state belonged to the BIMARU group, the proportion of undernourished would be higher. The overall specification is validated by the F-test.

The OLS and robust regression results on proportions of underweight children are given in Tables 3 and 4, respectively. These are as hypothesised.

Table 3

Determinants of Proportion of Underweight among Children <5 years (\%)

\begin{tabular}{|c|c|c|c|c|c|c|}
\hline \multirow[t]{2}{*}{ Source } & \multirow[t]{2}{*}{ SS } & \multirow[t]{2}{*}{ df } & \multirow{2}{*}{\multicolumn{2}{|c|}{ MS }} & \multicolumn{2}{|c|}{$\begin{array}{l}\text { Number of } \\
\text { Observations=17 }\end{array}$} \\
\hline & & & & & $\mathrm{F}(2,14)$ & $=14.97$ \\
\hline Model & 2.197 & 2 & \multicolumn{2}{|c|}{1.099} & Prob $>F$ & $=0.0003$ \\
\hline \multirow[t]{2}{*}{ Residual } & \multirow[t]{2}{*}{1.027} & \multirow[t]{2}{*}{14} & \multirow{2}{*}{\multicolumn{2}{|c|}{0.073}} & \multicolumn{2}{|c|}{ R-squared $=0.6814$} \\
\hline & & & & & \multicolumn{2}{|c|}{ Adj R-squared =0.6359 } \\
\hline Total & 3.224 & 16 & \multicolumn{2}{|c|}{0.202} & \multirow{2}{*}{\multicolumn{2}{|c|}{$\begin{array}{r}\text { Root MSE }=.27087 \\
{[95 \% \text { Conf. Interval }]}\end{array}$}} \\
\hline $\begin{array}{l}\text { Log of Proportion of } \\
\text { Underweight among Children } \\
<5 \text { years }(\%)\end{array}$ & Coef. & Std. Err. & $\mathrm{t}$ & $\mathrm{P}>|\mathrm{t}|$ & & \\
\hline $\begin{array}{l}\text { MPCE (Rs.) for the year } \\
\text { 2004-05 }\end{array}$ & -0.002 & 0.001 & -2.13 & 0.051 & -0.004 & 0.000 \\
\hline Female Literacy Rate & -0.016 & 0.008 & -2.04 & 0.061 & -0.033 & 0.001 \\
\hline cons & 1.358 & 0.340 & 3.99 & 0.001 & 0.628 & 2.088 \\
\hline
\end{tabular}

Table 4

Determinants of Proportion of Underweight among Children $<5$ years (\%) (Robust Regression)

\begin{tabular}{|l|l|}
\hline Robust Regression & Number of Observations $=17$ \\
\cline { 2 - 2 } & $\mathrm{F}(2,14)=13.12$ \\
\hline
\end{tabular}

${ }^{15}$ For a lucid and persuasive analysis, see Subramanian and Deaton, 1996. For an illustration of change of curvature in the Slutsky matrix, see Jha et al. 2009, following earlier contributions by Timmer, 1981, and Deolalikar and Behrman ,1987, 1988, 1989.

${ }^{16}$ Details will be furnished on request. 


\begin{tabular}{|c|c|c|c|c|c|c|}
\hline & & & & & \multicolumn{2}{|c|}{$\frac{\text { Prob }>F=0.0006}{[95 \% \text { Conf. Interval }]}$} \\
\hline $\begin{array}{l}\text { Log of Proportion of } \\
\text { Underweight among } \\
\text { Children }<5 \text { years (\%) }\end{array}$ & Coef. & Std. Err. & $\mathrm{t}$ & $\mathrm{P}>|\mathrm{t}|$ & {$[95 \%$} & \\
\hline $\begin{array}{l}\text { MPCE (Rs.) for the } \\
\text { year 2004-05 }\end{array}$ & -0.002 & 0.001 & -1.98 & 0.068 & -0.004 & 0.000 \\
\hline Female Literacy Rate & -0.016 & 0.008 & -1.93 & 0.075 & -0.034 & 0.002 \\
\hline _cons & 1.338 & 0.360 & 3.71 & 0.002 & 0.565 & 2.110 \\
\hline
\end{tabular}

The higher the MPCE, the lower was the prevalence of child undernutrition. Also, consistent with earlier findings, female literacy significantly lowers undernutrition. ${ }^{17}$ Both OLS and robust regressions confirm these effects. The overall specification is validated by the F-test.

Table 5

Determinants of Under-five Mortality Rate (\%)

\begin{tabular}{|c|c|c|c|c|c|c|}
\hline \multirow[t]{2}{*}{ Source } & \multirow[t]{2}{*}{ SS } & \multirow[t]{2}{*}{$\mathrm{df}$} & \multirow{2}{*}{\multicolumn{2}{|c|}{ MS }} & \multicolumn{2}{|c|}{$\begin{array}{l}\text { Number of } \\
\text { Observations }=17\end{array}$} \\
\hline & & & & & $F(5,11)$ & $=21.83$ \\
\hline Model & 3.450 & 5 & \multicolumn{2}{|c|}{0.690} & $\begin{array}{l}\text { Prob }>F \\
0.0000\end{array}$ & \\
\hline \multirow[t]{2}{*}{ Residual } & \multirow[t]{2}{*}{0.348} & \multirow[t]{2}{*}{11} & \multirow{2}{*}{\multicolumn{2}{|c|}{0.032}} & \multirow{2}{*}{\multicolumn{2}{|c|}{$\begin{array}{l}\text { R-squared = } \\
0.9085 \\
\text { Adj R-squared } \\
=0.8329\end{array}$}} \\
\hline & & & & & & \\
\hline Total & 3.798 & 16 & \multicolumn{2}{|c|}{0.237} & \multirow{2}{*}{\multicolumn{2}{|c|}{$\begin{array}{l}\text { Root MSE = } \\
0.17777 \\
{[95 \% \text { Conf. Interval }]}\end{array}$}} \\
\hline $\begin{array}{l}\text { Log of Under-five mortality } \\
\text { rate (deaths per hundred) }\end{array}$ & Coef. & Std. Err. & $\mathrm{t}$ & $\mathrm{P}>|\mathrm{t}|$ & & \\
\hline CPIAL for the year 2003-04 & 0.002 & 0.005 & 0.40 & 0.698 & -0.010 & 0.014 \\
\hline $\begin{array}{l}\text { Delta of CPIAL for the year } \\
2004-05 \text { and 2003-04 }\end{array}$ & 0.011 & 0.005 & 2.45 & 0.032 & 0.001 & 0.021 \\
\hline $\begin{array}{l}\text { Estimated Proportion of } \\
\text { underweight among children } \\
<5 \text { years without offtake (\%) }\end{array}$ & 0.019 & 0.012 & 1.57 & 0.144 & -0.007 & 0.045 \\
\hline Lorenz Ratio in year 2004-05 & 0.313 & 0.115 & 2.72 & 0.020 & 0.059 & 0.566 \\
\hline $\begin{array}{l}\text { Square of Lorenz Ratio in } \\
\text { year 2004-05 }\end{array}$ & -0.006 & 0.002 & -3.09 & 0.010 & -0.011 & -0.002 \\
\hline cons & -7.853 & 2.291 & -3.43 & 0.006 & -12.895 & -2.811 \\
\hline
\end{tabular}

Let us now turn to the determinants of under-five mortality rates. As we prefer robust regression results, we will confine our comments to Table 6. The higher the $\triangle$ CPIAL

\footnotetext{
${ }^{17}$ Our experiments with CPIAL, and PDS offtake did not yield significant results. Details will be furnished on request.
} 
(implying a reduction in real MPCE), the higher is the under-five mortality rate. The higher the proportion of underweight children, the higher is the mortality rate among under-five children. Recalling our earlier remark about inequality/the Gini coefficient adding an important dimension to deprivation (at the same level of MPCE), it is not surprising that there is a positive relationship between under-five mortality and inequality. However, this relationship weakens because of the negative coefficient of the square of the Gini. ${ }^{18}$ The overall specification is validated by the F-test.

Table 6

Determinants of Under-five Mortality Rate (\%) (Robust Regression)

\begin{tabular}{|c|c|c|c|c|c|c|}
\hline & \multicolumn{2}{|c|}{$\begin{array}{l}\text { Number of Observations }=16 \\
F(5,10)=29.02\end{array}$} \\
\hline \multicolumn{5}{|l|}{ Robust Regression } & \multirow{2}{*}{\multicolumn{2}{|c|}{$\begin{array}{l}\text { Prob }>\mathrm{F}=0.0000 \\
{[95 \% \text { Conf. Interval }]}\end{array}$}} \\
\hline $\begin{array}{l}\text { Log of Under-five mortality } \\
\text { rate (deaths per hundred) }\end{array}$ & Coef. & Std. Err. & $\mathrm{t}$ & $\mathrm{P}>|\mathrm{t}|$ & & \\
\hline CPIAL for the year 2003-04 & -0.003 & 0.005 & -0.60 & 0.560 & -0.015 & 0.009 \\
\hline $\begin{array}{l}\text { Delta of CPIAL for the year } \\
2004-05 \text { and } 2003-04\end{array}$ & 0.008 & 0.004 & 1.86 & 0.092 & -0.002 & 0.017 \\
\hline $\begin{array}{l}\text { Estimated Proportion of } \\
\text { underweight among } \\
\text { children }<5 \text { years without } \\
\text { offtake (\%) }\end{array}$ & 0.029 & 0.011 & 2.61 & 0.026 & 0.004 & 0.053 \\
\hline $\begin{array}{l}\text { Lorenz Ratio in year 2004- } \\
05\end{array}$ & 0.419 & 0.112 & 3.72 & 0.004 & 0.168 & 0.669 \\
\hline $\begin{array}{l}\text { Square of Lorenz Ratio in } \\
\text { vear 2004-05 }\end{array}$ & -0.007 & 0.002 & -3.96 & 0.003 & -0.012 & -0.003 \\
\hline cons & -8.623 & 2.041 & -4.22 & 0.002 & -13.171 & -4.074 \\
\hline
\end{tabular}

\section{(b) Undernutrition and Poverty}

To further validate our econometric specifications and to link various indicators to poverty, some graphs are given below.

\footnotetext{
18 Although somewhat outdated, Radhakrishna and Subbarao, 1997, estimated the cost (in rupees) per rupee of income transfer of five anti-poverty programmes to have been as follows during 1988-90: PDS, 5.37; rice subsidy scheme of the state of Andhra Pradesh, 6.35; a national employment programme for the poor, 4.34; the employment guarantee scheme of the state of Maharashtra 3.1; and Integrated Child Development Services, 1.8. On this, see also Srinivasan, 2000, and Gaiha and Kulkarni, 2006.
} 
Fig: 1Estimated and Actual Calorie Deficiency (\%) by Headcount Ratio (\%)
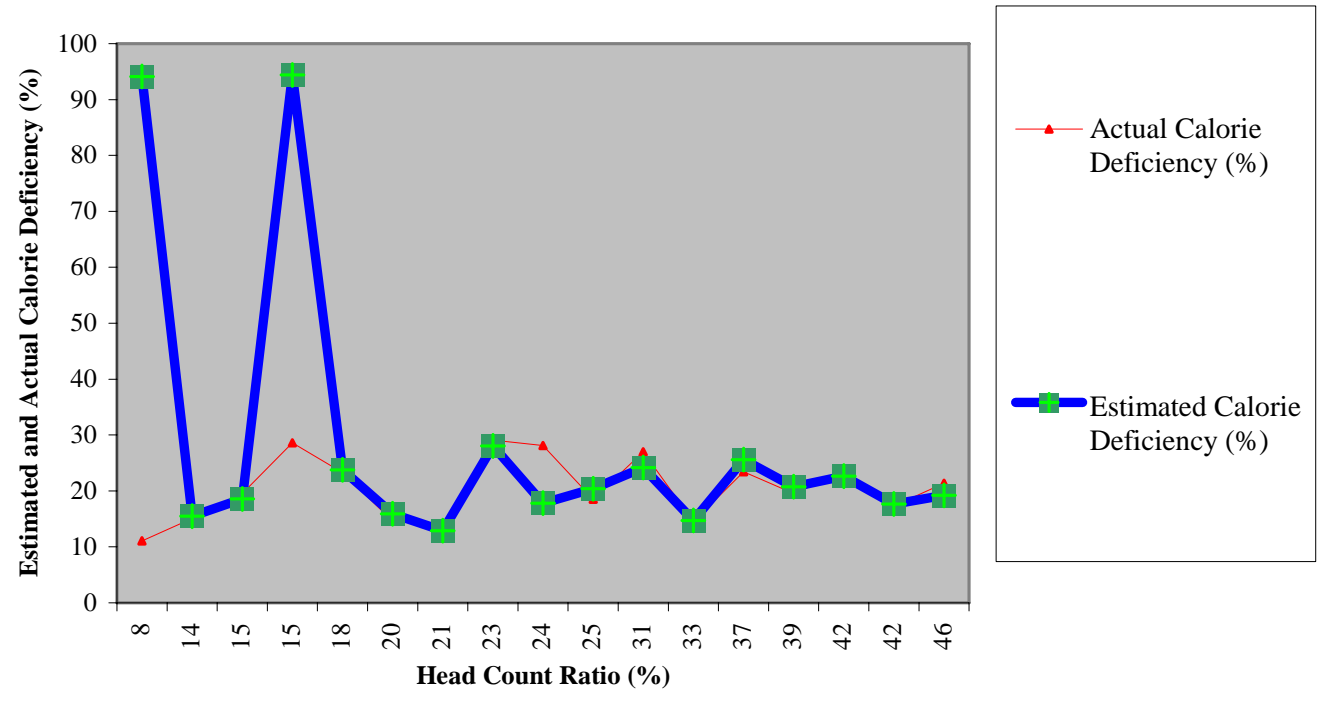

Except for two outliers in Fig: 1, generally the predicted values of prevalence of calorie deficiency track closely the actual ${ }^{19}$. Another but somewhat surprising feature of this graph is that there is no indication of a positive relationship between calorie deficiency and poverty.

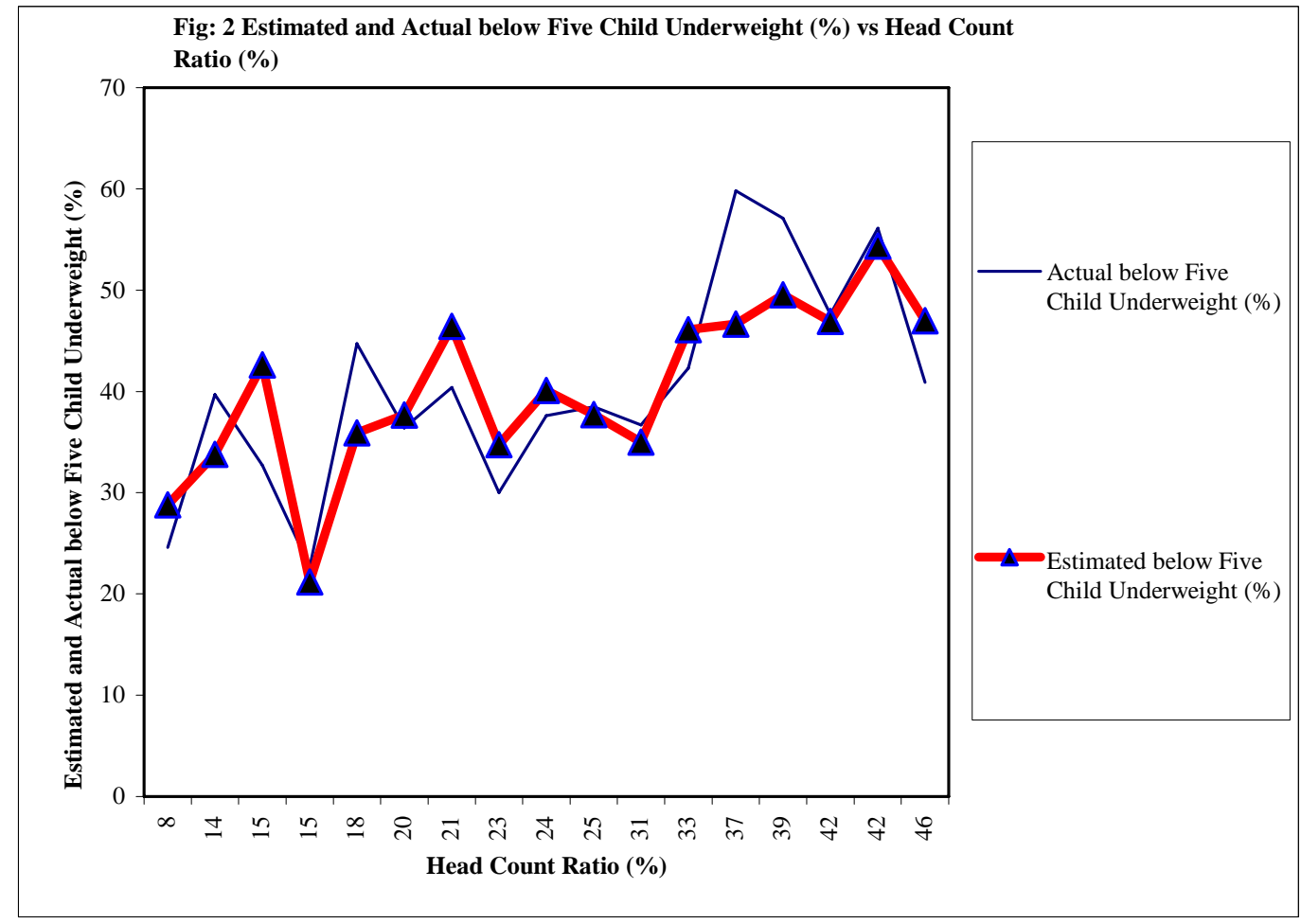

${ }^{19}$ These are Kerala and Punjab. Both have low poverty rates but relatively high CPIAL. 
By contrast, Fig: 2 not only portrays generally more accurate predictions but also a positive relationship between the proportion of underweight children and poverty. In other words, the more pervasive is poverty, the greater is the proportion of underweight children. Similarly in Fig: 3, the predicted mortality rates for under-five children follow closely the actual. Besides, there is a positive relationship between mortality rate and poverty.

In sum, as discussed earlier, the determinants of different indicators of undernutrition vary. At least two-proportion of underweight children and under-five mortality rate- rise with poverty.

\section{(c) Analysis of Residuals}

Following a standard practice, we investigate whether the residuals vary systematically with an omitted variable. In various writings, Sen, 1997, and Dreze and Sen, 1989, have drawn attention to the important role of the media in averting famines and mortality.

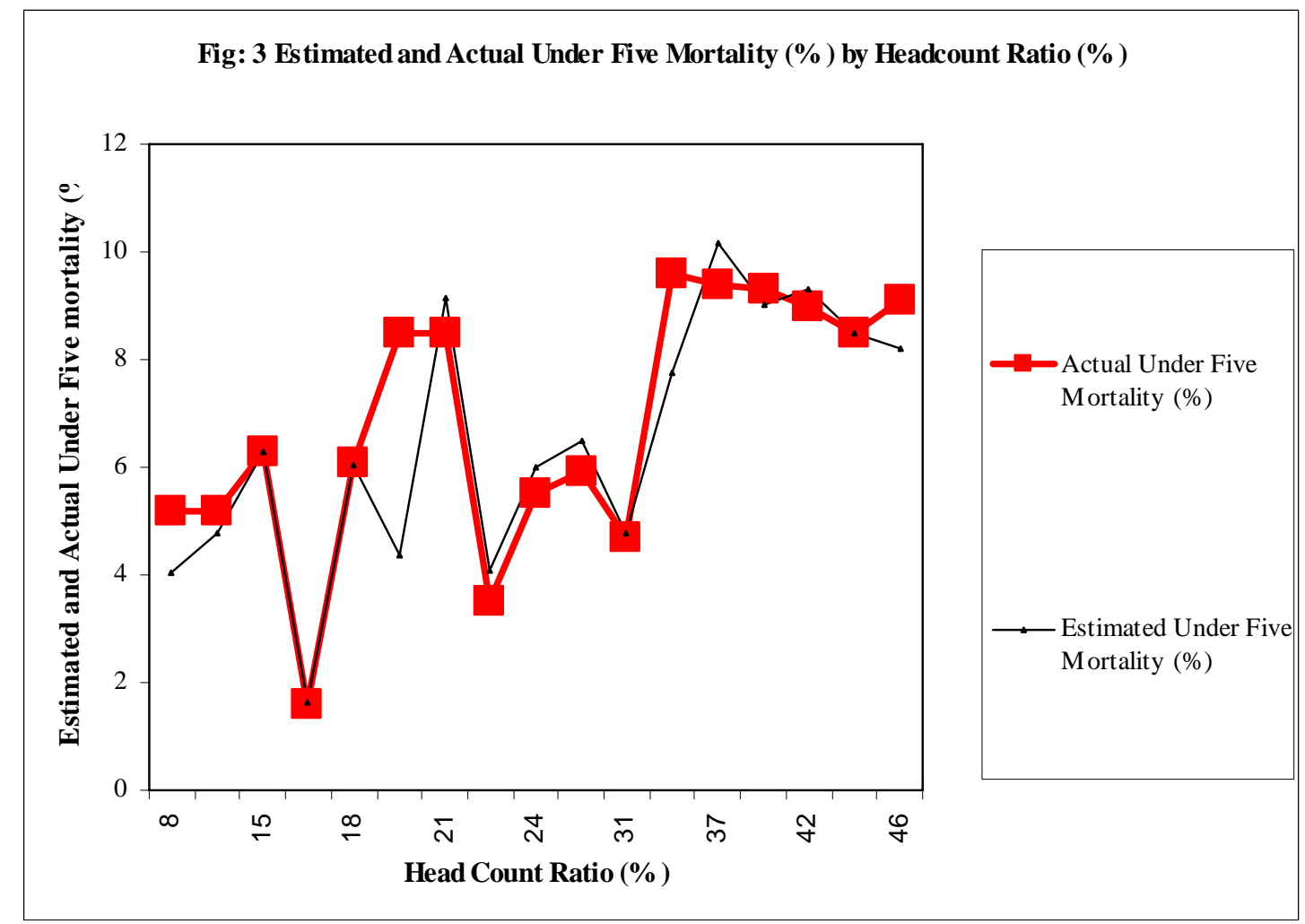

Accordingly, in Tables 7-12, we give the results of our analysis of the residuals of calorie deficient population, underweight children under-five, and deaths of under-five children. 
Table 7

Newspaper Circulation as a Determinant of Residuals of Prevalence of Calorie Under-Nourishment (\%)

\begin{tabular}{|c|c|c|c|c|c|c|}
\hline \multirow[t]{2}{*}{ Source } & \multirow[t]{2}{*}{ SS } & \multirow[t]{2}{*}{ df } & \multirow{2}{*}{\multicolumn{2}{|c|}{ MS }} & \multicolumn{2}{|c|}{$\begin{array}{l}\text { Number of } \\
\text { Observations }=17\end{array}$} \\
\hline & & & & & \multicolumn{2}{|c|}{$F(2,14)=0.07$} \\
\hline Model & 103.21 & 2 & \multicolumn{2}{|c|}{51.60} & \multicolumn{2}{|c|}{ Prob $>F=0.9315$} \\
\hline \multirow{2}{*}{ Residual } & \multirow{2}{*}{10136.07} & \multirow{2}{*}{14} & \multirow{2}{*}{\multicolumn{2}{|c|}{724.01}} & \multicolumn{2}{|c|}{ R-squared $=0.0101$} \\
\hline & & & & & \multicolumn{2}{|c|}{ Adj R-squared $=-0.1313$} \\
\hline Total & 10239.28 & 16 & \multicolumn{2}{|c|}{639.96} & Root MSE & 907 \\
\hline $\begin{array}{l}\text { Residuals of Prevalence of calorie } \\
\text { under-nourishment (\%) }\end{array}$ & Coef. & Std. Err. & $\mathrm{t}$ & $P>|t|$ & \multicolumn{2}{|c|}{ [95\% Conf. Interval] } \\
\hline Newspaper circulations (Lakh) & 0.004 & 0.251 & 0.02 & 0.988 & -0.534 & 0.542 \\
\hline $\begin{array}{l}\text { Square of Newspaper circulations } \\
\text { (Lakh) }\end{array}$ & 0.000 & 0.001 & 0.11 & 0.914 & -0.002 & 0.002 \\
\hline _cons & -9.537 & 13.707 & -0.70 & 0.498 & -38.936 & 19.862 \\
\hline
\end{tabular}

Note: The Breusch-Pagan / Cook-Weisberg test is used to test for heteroscedasticity. The chi-square statistic with 2 degrees of freedom (1.13) and corresponding probability value (0.5681) suggest that the null hypothesis of constant variance is not rejected.

Table 8

Newspaper Circulation as a Determinant of Residuals of Prevalence of Calorie Under-Nourishment (\%) (Robust Regression)

\begin{tabular}{|c|c|c|c|c|c|c|}
\hline \multirow{3}{*}{ Robust Regression } & & & & & \multicolumn{2}{|c|}{ Number of Observations $=17$} \\
\hline & & & & & \multicolumn{2}{|c|}{$F(2,14)=0.21$} \\
\hline & & & & & \multicolumn{2}{|c|}{ Prob $>F=0.8163$} \\
\hline $\begin{array}{l}\text { Residuals of Prevalence of calorie } \\
\text { under-nourishment (\%) }\end{array}$ & Coef. & Std. Err. & $\mathrm{t}$ & $P>|t|$ & \multicolumn{2}{|c|}{ [95\% Conf. Interval] } \\
\hline Newspaper circulations (Lakh) & 0.010 & 0.019 & 0.55 & 0.591 & -0.030 & 0.050 \\
\hline $\begin{array}{l}\text { Square of Newspaper circulations } \\
\text { (Lakh) }\end{array}$ & 0.000 & 0.000 & -0.63 & 0.540 & 0.000 & 0.000 \\
\hline _cons & -0.321 & 1.015 & -0.32 & 0.756 & -2.498 & 1.856 \\
\hline
\end{tabular}

Tables 7-8 confirm that there is no systematic relationship between prevalence of calorie deficiency and newspaper circulation. This is perhaps not as surprising as hunger/undernutrition in this form has no visible impact. Residuals of the other two indicators, however, display robust relationships. Table 10, for example, suggests that the residuals diminish with newspaper circulation but at a slower rate. This implies that the 
greater the media exposure, the lower would be the gap between the actual and predicted proportions of underweight children. In other words, the lower would be the prospects of excess of actual proportion of underweight children. This evidence is suggestive of the role of the media in averting child undernutrition-especially in its more visible forms. ${ }^{20}$

Table 9

Newspaper circulation as a Determinant of Residuals of Proportion of Underweight among Children $<5$ years $(\%)$

\begin{tabular}{|c|c|c|c|c|c|c|}
\hline \multirow{2}{*}{ Source } & \multirow{2}{*}{ SS } & \multirow{2}{*}{$\mathrm{df}$} & \multirow{2}{*}{\multicolumn{2}{|c|}{ MS }} & \multicolumn{2}{|c|}{ Number of Observations $=17$} \\
\hline & & & & & \multicolumn{2}{|c|}{$F(2,14)=0.03$} \\
\hline Model & 2.48 & 2 & \multicolumn{2}{|c|}{1.24} & \multicolumn{2}{|c|}{ Prob $>F=0.9707$} \\
\hline \multirow{2}{*}{ Residual } & \multirow{2}{*}{583.15} & \multirow{2}{*}{14} & \multirow{2}{*}{\multicolumn{2}{|c|}{41.65}} & \multicolumn{2}{|c|}{ R-squared $=0.0042$} \\
\hline & & & & & \multicolumn{2}{|c|}{ Adj R-squared $=-0.1380$} \\
\hline Total & 585.63 & 16 & \multicolumn{2}{|c|}{36.60} & Root MSE & 539 \\
\hline $\begin{array}{l}\text { Residuals of Proportion of } \\
\text { Underweight among Children }<5 \\
\text { years (\%) }\end{array}$ & Coef. & Std. Err. & $\mathrm{t}$ & $P>|t|$ & \multicolumn{2}{|c|}{ [95\% Conf. Interval] } \\
\hline Newspaper circulations (Lakh) & 0.014 & 0.060 & 0.24 & 0.813 & -0.115 & 0.144 \\
\hline $\begin{array}{l}\text { Square of Newspaper circulations } \\
\text { (Lakh) }\end{array}$ & 0.000 & 0.000 & -0.21 & 0.833 & 0.000 & 0.000 \\
\hline _cons & -0.512 & 3.288 & -0.16 & 0.879 & -7.563 & 6.540 \\
\hline
\end{tabular}

Note: The Breusch-Pagan / Cook-Weisberg test is used to test for heteroscedasticity. The chi-square statistic with 2 degrees of freedom (2.52) and corresponding probability value (0.2836) suggest that the null hypothesis of constant variance is not rejected.

Table 10

Newspaper Circulation as a Determinant of Residuals of Proportion of Underweight among Children $<5$ years (\%) (Robust Regression)

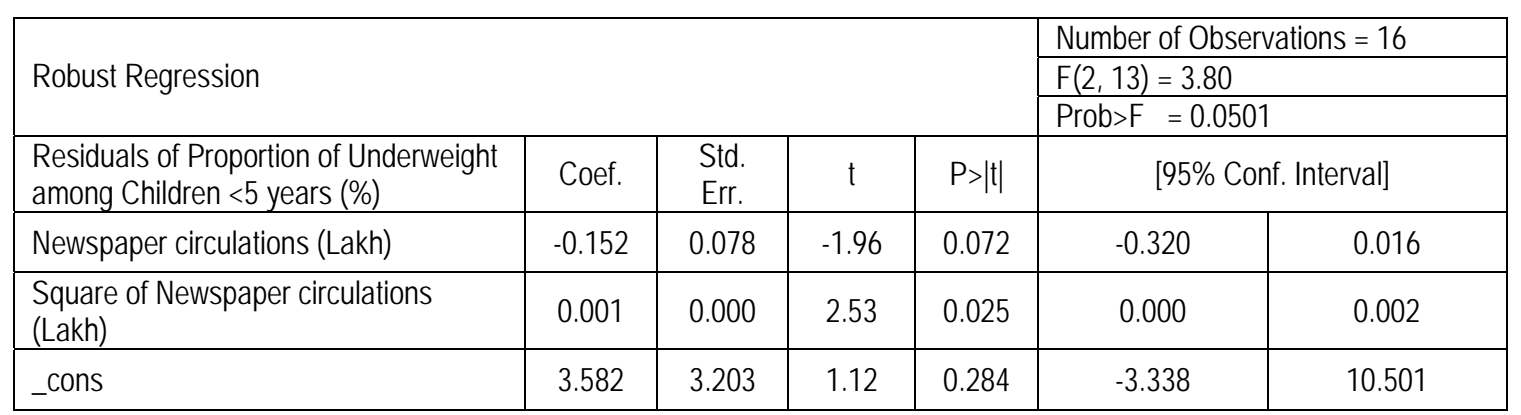

${ }^{20}$ For a recent comment, see Kapoor, 2009. 
Table 11

Newspaper Circulation as a Determinant of Residuals of Under-five Mortality Rate (\%)

\begin{tabular}{|c|c|c|c|c|c|c|}
\hline \multirow{2}{*}{ Source } & \multirow{2}{*}{ SS } & \multirow{2}{*}{$\mathrm{df}$} & \multirow{2}{*}{\multicolumn{2}{|c|}{ MS }} & \multicolumn{2}{|c|}{ Number of Observations $=17$} \\
\hline & & & & & \multicolumn{2}{|c|}{$F(2,14)=3.80$} \\
\hline Model & 8.19 & 2 & \multicolumn{2}{|c|}{5.00} & \multicolumn{2}{|c|}{ Prob $>F=0.0480$} \\
\hline \multirow{2}{*}{ Residual } & \multirow{2}{*}{15.08} & \multirow{2}{*}{14} & \multirow{2}{*}{\multicolumn{2}{|c|}{1.08}} & \multicolumn{2}{|c|}{ R-squared $=0.3520$} \\
\hline & & & & & \multicolumn{2}{|c|}{ Adj R-squared $=-0.2594$} \\
\hline Total & 23.28 & 16 & \multicolumn{2}{|c|}{1.45} & \multicolumn{2}{|c|}{ Root MSE $\quad=1.038$} \\
\hline $\begin{array}{l}\text { Residuals of Under-five Mortality Rate } \\
(\%)\end{array}$ & Coef. & Std. Err. & $\mathrm{t}$ & $P>|t|$ & \multicolumn{2}{|c|}{ [95\% Conf. Interval] } \\
\hline Newspaper circulations (Lakh) & -0.026 & 0.010 & -2.64 & 0.019 & -0.046 & -0.005 \\
\hline $\begin{array}{l}\text { Square of Newspaper circulations } \\
\text { (Lakh) }\end{array}$ & 0.000 & 0.000 & 2.76 & 0.015 & 0.000 & 0.000 \\
\hline _cons & 1.397 & 0.529 & 2.64 & 0.019 & 0.263 & 2.531 \\
\hline
\end{tabular}

Note: The Breusch-Pagan / Cook-Weisberg test is used to test for heteroscedasticity. The chi-square statistic with 2 degrees of freedom (11.82) and corresponding probability value (0.0027) suggest that the null hypothesis of constant variance is rejected at $1 \%$ level of significance.

Both Tables 11-12 corroborate the important role of the media in averting the excess of child mortality as well. More specifically, with higher newspaper circulation, the residuals decrease but at a diminishing rate. Constrained by the data, we are unable to examine whether 'local' newspapers are more effective in performing this function than national newspapers.

Table 12

Newspaper Circulation as a Determinant of Residuals of Under-five Mortality Rate (\%) (Robust Regression)

\begin{tabular}{|c|c|c|c|c|c|c|}
\hline \multirow{3}{*}{ Robust Regression } & & & & & \\
\hline & & & & & & \\
\hline & & & & & \multicolumn{2}{|c|}{$\begin{array}{l}F(2,14)=5.23 \\
\text { Prob }>F=0.0201\end{array}$} \\
\hline $\begin{array}{l}\text { Residuals of Under-five Mortality } \\
\text { Rate (\%) }\end{array}$ & Coef. & Std. Err. & $\mathrm{t}$ & $P>|t|$ & \multicolumn{2}{|c|}{ [95\% Conf. Interval] } \\
\hline Newspaper circulations (Lakh) & -0.014 & 0.006 & -2.41 & 0.030 & -0.026 & -0.002 \\
\hline $\begin{array}{l}\text { Square of Newspaper } \\
\text { circulations (Lakh) }\end{array}$ & 0.000 & 0.000 & 2.99 & 0.010 & 0.000 & 0.000 \\
\hline _cons & 0.559 & 0.313 & 1.78 & 0.096 & -0.113 & 1.231 \\
\hline
\end{tabular}




\section{(e) Simulations}

To illustrate policy priorities, counterfactual simulation results are summarised below.

- A 10 percent reduction in the (mean) CPIAL reduces prevalence of calorie deficiency from 28.58 per cent to 17.31 per cent, a sharp reduction.

- If the (mean) MPCE rises by 10 per cent, the prevalence of calorie deficiency drops to 19.03 per cent.

- A reduction in rural -urban disparity-say, the ratio of rural MPCE to urban MPCE rises by 10 per cent-reduces the prevalence to 20.34 per cent. An increase in the rural/urban MPCE by 20 per cent reduces it to about 14 per cent.

- Turning to the proportion of underweight among under-five children, a 10 per cent higher MPCE has a negligible effect - the (mean) proportion falls from 39.93 per cent to 38.05 per cent.

- Somewhat surprisingly, the effect of higher female literacy is small too. A 10 per cent higher female literacy reduces the proportion of underweight children to 37.66 per cent.

- If the increase in $\triangle \mathrm{CPIAL}$ is 10 per cent, the (mean) under-five mortality rate rises slightly — from 6.88 per cent to 6.95 per cent. A 20 per cent higher value raises the mortality rate to 7.02 per cent.

- If the proportion of underweight children falls by 10 per cent, the (mean) mortality rate falls to 6.18 per cent; a 20 per cent reduction in the former reduces it to 5.55 per cent.

- Substantial reduction in income inequality, measured by the Gini coefficient, is associated with sharp reduction in under-five mortality rate. If, for example, the Gini reduces by 30 per cent-a substantial reduction that may not be feasible without a drastic reordering of social and economic arrangements-the mortality rate drops to 5.15 per cent. If the Gini reduces by 40 per cent, the mortality rate falls to 3.5 per cent.

In sum, MPCE alone is unlikely to reduce different forms of undernutrition. Reduction of rural/urban disparity, consumer price stabilisation, and female literacy also play important roles of varying degrees. Above all, conditional upon drastic social and economic restructuring, substantial reduction in income inequality holds much potential for reducing child mortality. 


\section{Concluding Observations}

Despite accelerated growth there is pervasive hunger, child undernutrition and mortality. In fact, some of these indicators are the worst in the world. Our analysis focused on their determinants.

If calorie deficiency is taken as a measure of hunger, its pervasiveness reflects low living standards, high consumer prices, rural/urban disparity in living standards, and general backwardness of a state (weak infrastructure, acute deprivation, and low literacy rates as in BIMARU states).

Proportion of underweight five-year old children varies inversely with living standards, and female literacy rate.

Under-five mortality rate varies inversely with increase in consumer prices, positively with the proportion of underweight five-year old children, and non-linearly with the Gini of living standards (i.e. positively with the Gini and negatively with the square of the Gini). But, in general, except for calorie-deficiency prevalence, child undernutrition and mortality rise with poverty. However, raising living standards alone will not reduce hunger and undernutrition. Reduction of rural/urban disparities, consumer price stabilisation, mothers' literacy have all roles of varying importance in different nutrition indicators. Somewhat surprisingly, offtake from the PDS does not have a significant effect on any of the three indicators considered here.

Broadening the focus of the analysis, we examined the 'excess' of hunger and undernutrition (i.e. the excess of actual over predicted values) as functions of media exposure (measured in terms of newspaper circulation). Our analysis confirms that media exposure helps avert child undernutrition and mortality. Indeed, the mass media have a key role in triggering public action. The latter involves:

not only food production and agricultural expansion, but also the functioning of the entire economy, and even — more broadly - the operation of the political and social arrangements that can, directly or indirectly, influence people's ability to acquire food and to achieve health and nourishment. (Sen, 1997, p. 23)

If evidence is needed in support of this view, it lies in a drastic reduction of economic inequality as a precondition for reducing child mortality. 


\section{References}

Behrman, J. and A. Deolalikar (1987), 'Will Developing Country Nutrition Improve with Income? A Case Study for Rural South India’, Journal of Political Economy, vol. 95.

Behrman, J. and A. Deolalikar (1988), 'Health and Nutrition', in H. Chenery and T. N. Srinivasan (eds) Handbook of Development Economics, vol. 1, Amsterdam: Elsevier Science Publishers B.V.

Behrman, J. and A. Deolalikar (1989), 'Is Variety the Spice of Life? Implications for Calorie Intake’ Review of Economics and Statistics, vol. 71, no.4, pp. 666-672.

Bozzoli, C., A. Deaton, and C. Quintana-Domeque (2007), 'Child Mortality, Income and Adult Height', NJ: Princeton University, Research Programme in Development Studies, (mimeo).

Dasgupta, P. (1993), An Inquiry into Well-Being and Destitution. Oxford: Oxford University Press.

Deaton, A. and J. Dreze (2002), ‘Poverty and Inequality in India: A Re-examination', Economic and Political Weekly, Vol 37, No 36, September 7.

Deaton, A. and J. Dreze (2008), ‘Nutrition in India: Facts and Interpretations’ (mimeo).

Dreze, J. and Amartya Sen (eds) (1990), The Political Economy of Hunger, vol. III, Oxford: Clarendon Press.

Gaiha, R. (1999), 'Food Prices and Income in India’, Canadian Journal of Development Studies, vol. xx.

Gaiha, R. and Veena S. Kulkarni (2005), 'Anthropometric Failure and Persistence of Poverty in Rural India', International Review of Applied Economics, Vol. 19, No. 2, 179-197.

Gaiha, R., G. Thapa, K. Imai and Vani S. Kulkarni (2008), 'Has Anything Changed? Deprivation, Disparity, and Discrimination in Rural India’, Brown Journal of World Affairs, vol. xiv, no.2.

Himanshu (2007), 'Recent Trends in Poverty and Inequality: Some Preliminary Results', Economic and Political Weekly, 10 February.

Jha, R., R. Gaiha and A. Sharma (2009 a), 'Mean Consumption, Poverty and Inequality in Rural India in the Sixtieth Round of the National Sample Survey’, Journal of Asian and African Studies (forthcoming).

Jha, R., R. Gaiha and A. Sharma (2009 b), 'Calorie and Micronutrient Deprivation and Poverty - Nutrition Traps in Rural India’, World Development, May.

Jha, R., R. Gaiha and A. Sharma (2009 c), 'On Modelling Variety in Consumption Expenditure on Food', International Review of Applied Economics (forthcoming).

Jha, R., R. Gaiha and A. Sharma (2009 d), 'Is There Curvature in the Slutsky Matrix-Analysis with Indian Data', draft.

Menon, P., A. Deolalikar and A. Bhaskar (2009), 'India State Hunger Index: Comparisons of Hunger Across States', Washington DC: IFPRI.

Sen, Amartya (1997), 'Hunger in the Contemporary World', London: LSE-STICERD Research Paper No. DEDPS 08.

Sridhar, D. (2008) The Battle against Hunger, New York: Oxford University Press.

Srinivasan, T. N. (1981), 'Malnutrition: Some Measurement and Policy Issues', Journal of Development Economics, vol. 8.

Srinivasan, T. N. (1992), 'Undernutrition: Concepts, Measurements and Policy Implications', in S. Osmani, (ed.) Nutrition and Poverty, Delhi: Oxford University Press.

Srinivasan, T. N. (1994), ‘Destitution: A Discourse’, Journal of Economic Literature, vol. 32.

Srinivasan, T. N. (2000), 'Poverty and Undernutrition in South Asia’, Food Policy, vol. 25.

Strauss, J. and D. Thomas (1998), 'Health, Nutrition, and Economic Development'. Journal of Economic Literature, Vol. 36, No. 2.

Subramaniam, S. and A. Deaton (1996), 'The Demand for Food and Calories', Journal of Political Economy, vol. 1004, no.1.

Timmer, C. P. (1981), 'Is There 'Curvature' in the Slutsky Matrix?', The Review of Economics and Statistics, Vol. 63, No. 3 (Aug., 1981). 
Annex

Table A.1. Definitions and Descriptive Statistics of Variables Used in the Analysis

\begin{tabular}{|c|c|c|c|c|c|c|}
\hline Variable Name & Definitions & $\mathbf{N}$ & Mean & SD & Min & Max \\
\hline \multicolumn{7}{|c|}{ Dependent Variables } \\
\hline $\begin{array}{l}\text { Log of Prevalence of calorie under- } \\
\text { nourishment (\%) }\end{array}$ & $\begin{array}{l}\text { Log of Prevalence of calorie under- } \\
\text { nourishment (\%) in 2005-06 }\end{array}$ & 17 & -1.39 & 0.36 & -2.08 & -0.89 \\
\hline $\begin{array}{l}\text { Log of Proportion of Underweight } \\
\text { among Children }<5 \text { years }(\%)\end{array}$ & $\begin{array}{l}\text { Log of Proportion of Underweight among } \\
\text { Children }<5 \text { years (\%) in 2005-06 }\end{array}$ & 17 & -0.40 & 0.45 & -1.23 & 0.40 \\
\hline $\begin{array}{l}\text { Log of Under-five mortality rate } \\
\text { (deaths per hundred) }\end{array}$ & $\begin{array}{l}\text { Log of Under-five mortality rate (deaths } \\
\text { per hundred) in 2004-05 }\end{array}$ & 17 & -2.70 & 0.49 & -4.12 & -2.24 \\
\hline $\begin{array}{l}\text { Residuals of Prevalence of calorie } \\
\text { under-nourishment (\%) }\end{array}$ & $\begin{array}{l}\text { Actual minus Estimated Prevalence of } \\
\text { calorie under-nourishment (\%) }\end{array}$ & 17 & -8.11 & 25.30 & -83.03 & 10.28 \\
\hline $\begin{array}{l}\text { Residuals of Proportion of } \\
\text { Underweight among Children }<5 \\
\text { years (\%) }\end{array}$ & $\begin{array}{l}\text { Actual minus Estimated Proportion of } \\
\text { Underweight among Children }<5 \text { years } \\
(\%)\end{array}$ & 17 & 0.19 & 6.05 & -9.93 & 13.14 \\
\hline $\begin{array}{l}\text { Residuals of Under-five Mortality } \\
\text { Rate (\%) }\end{array}$ & $\begin{array}{l}\text { Actual minus Estimated Under-five } \\
\text { Mortality Rate (\%) }\end{array}$ & 17 & 0.32 & 1.21 & -0.75 & 4.15 \\
\hline Percentage off take in year 2003-04 & Percentage off take in year 2003-04 & 17 & 53.71 & 22.82 & 9.02 & 86.63 \\
\hline \multicolumn{7}{|c|}{ Explanatory Variables } \\
\hline MPCE (Rs.) for year 2004-05 & MPCE (Rs.) for year 2004-05 & 17 & 388.91 & 99.26 & 261.49 & 597.96 \\
\hline $\begin{array}{l}\text { Square of MPCE (Rs.) for year } \\
2004-05\end{array}$ & Square of MPCE (Rs.) for year 2004-05 & 17 & 160522.5 & 85538.75 & 68376.97 & 357555.8 \\
\hline $\begin{array}{l}\text { Ratio of Rural to Urban MPCE for } \\
\text { year 2004-05 }\end{array}$ & $\begin{array}{l}\text { Ratio of Rural to Urban MPCE for year } \\
2004-05\end{array}$ & 17 & 0.61 & 0.12 & 0.49 & 0.87 \\
\hline CPIAL for the year 2004-05 & CPIAL for the year 2004-05 & 17 & 345.03 & 13.39 & 319.50 & 372.04 \\
\hline $\begin{array}{l}\text { Square of CPIAL for the year 2004- } \\
05\end{array}$ & Square of CPIAL for the year 2004-05 & 17 & 119215.6 & 9180.74 & 102080.3 & 138415.0 \\
\hline CPIAL for the year 2003-04 & CPIAL for the year 2003-04 & 17 & 330.93 & 13.54 & 311.00 & 348.75 \\
\hline $\begin{array}{l}\text { Square of CPIAL for the year 2003- } \\
04\end{array}$ & Square of CPIAL for the year 2003-04 & 17 & 109690.3 & 8920.45 & 96721.00 & 121626.6 \\
\hline $\begin{array}{l}\text { Delta of CPIAL for the year 2004-05 } \\
\text { and 2003-04 }\end{array}$ & $\begin{array}{l}\text { CPIAL for the year 2004-05 minus CPIAL } \\
\text { for the year 2003-04 }\end{array}$ & 17 & 14.10 & 11.86 & -1.58 & 37.63 \\
\hline Dummy for BIMARU States & $\begin{array}{l}1 \text { if States are Bihar, Madhya Pradesh, } \\
\text { Rajasthan and Uttar Pradesh, } 0 \text { otherwise }\end{array}$ & 17 & 0.24 & 0.44 & 0 & 1 \\
\hline Female Literacy Rate & $\begin{array}{l}\text { Female Literacy Rate of age 15-49 years } \\
\text { in 2005-06 }\end{array}$ & 17 & 59.88 & 12.24 & 39.60 & 90.00 \\
\hline Lorenz Ratio in year 2004-05 & Lorenz Ratio or Gini in year 2004-05 & 17 & 30.22 & 4.48 & 21.36 & 38.95 \\
\hline $\begin{array}{l}\text { Square of Lorenz Ratio in year } \\
2004-05\end{array}$ & Square of Lorenz Ratio in year 2004-05 & 17 & 932.28 & 264.62 & 456.44 & 1517.33 \\
\hline Head Count Ratio (\%) & Head Count Ratio in year 2004-05 (\%) & 17 & 26.71 & 11.53 & 8.22 & 46.44 \\
\hline Square of Head Count Ratio (\%) & $\begin{array}{l}\text { Square of Head Count Ratio in year 2004- } \\
05(\%)\end{array}$ & 17 & 838.68 & 653.47 & 67.57 & 2156.67 \\
\hline $\begin{array}{l}\text { Estimated Proportion of underweight } \\
\text { among children }<5 \text { years without } \\
\text { offtake (\%) (IV) }\end{array}$ & $\begin{array}{l}\text { Estimated Proportion of underweight } \\
\text { among children }<5 \text { years without offtake } \\
(\%)(I V)\end{array}$ & 17 & 40.27 & 8.37 & 21.18 & 54.34 \\
\hline Newspaper circulations (Lakh) & Newspaper circulations (Lakh) in 2005-06 & 17 & 83.81 & 81.27 & 9.04 & 332.92 \\
\hline $\begin{array}{l}\text { Square of Newspaper circulations } \\
\text { (Lakh) }\end{array}$ & $\begin{array}{l}\text { Square of Newspaper circulations (Lakh) } \\
\text { in 2005-06 }\end{array}$ & 17 & 13240.4 & 27015.27 & 81.67 & 110834.9 \\
\hline
\end{tabular}




\section{Endogeneity of Offtake of PDS}

As food obtained from the PDS is likely to be greater when consumer prices are high, we regress the former on CPIAl and (CPIAL) ${ }^{2}$. Both OLS and robust regression results point to a non-linear relationship between offtake and CPIAL. At higher values of CPIAL, the negative coefficient of CPIAL is more than offset by the positive coefficient of (CPIAL) ${ }^{2}$. Thus the higher the CPIAL the greater is likely to be the offtake.

Table A.2

Determinants of Percentage Offtake of PDS in year 2003-04

\begin{tabular}{|c|c|c|c|c|c|c|}
\hline \multirow{2}{*}{ Source } & \multirow{2}{*}{ SS } & \multirow{2}{*}{ df } & \multirow{2}{*}{\multicolumn{2}{|c|}{ MS }} & \multicolumn{2}{|c|}{ Number of Observations $=17$} \\
\hline & & & & & $F(2,14)=1$ & \\
\hline Model & 1556.868 & 2 & & & Prob>F & 2349 \\
\hline \multirow{2}{*}{ Residual } & \multirow{2}{*}{6772.619} & \multirow{2}{*}{14} & \multirow{2}{*}{\multicolumn{2}{|c|}{483.759}} & \multicolumn{2}{|c|}{ R-squared $=0.1869$} \\
\hline & & & & & \multicolumn{2}{|c|}{ Adj R-squared $=0.0708$} \\
\hline Total & 8329.487 & 16 & \multicolumn{2}{|c|}{520.593} & \multirow{2}{*}{\multicolumn{2}{|c|}{$\begin{array}{r}\text { Root MSE = } 21.995 \\
{[95 \% \text { Conf. Interval] }}\end{array}$}} \\
\hline Percentage off take in year 2003-04 & Coef. & Std. Err. & $\mathrm{t}$ & $P>|t|$ & & \\
\hline CPIAL for the year 2003-04 & -56.152 & 31.418 & -1.79 & 0.096 & -123.537 & 11.234 \\
\hline Square of CPIAL for the year 2003-04 & 0.085 & 0.048 & 1.79 & 0.095 & -0.017 & 0.188 \\
\hline _cons & 9275.832 & 5166.321 & 1.80 & 0.094 & -1804.830 & 20356.490 \\
\hline
\end{tabular}

Note: The Breusch-Pagan / Cook-Weisberg test is used to test for heteroscedasticity. The chi-square statistic with 2 degrees of freedom (0.98) and corresponding probability value (0.6138) suggest that the null hypothesis of constant variance is not rejected.

Table A.2.1

Determinants of Percentage Offtake of PDS in year 2003-04 (Robust Regression)

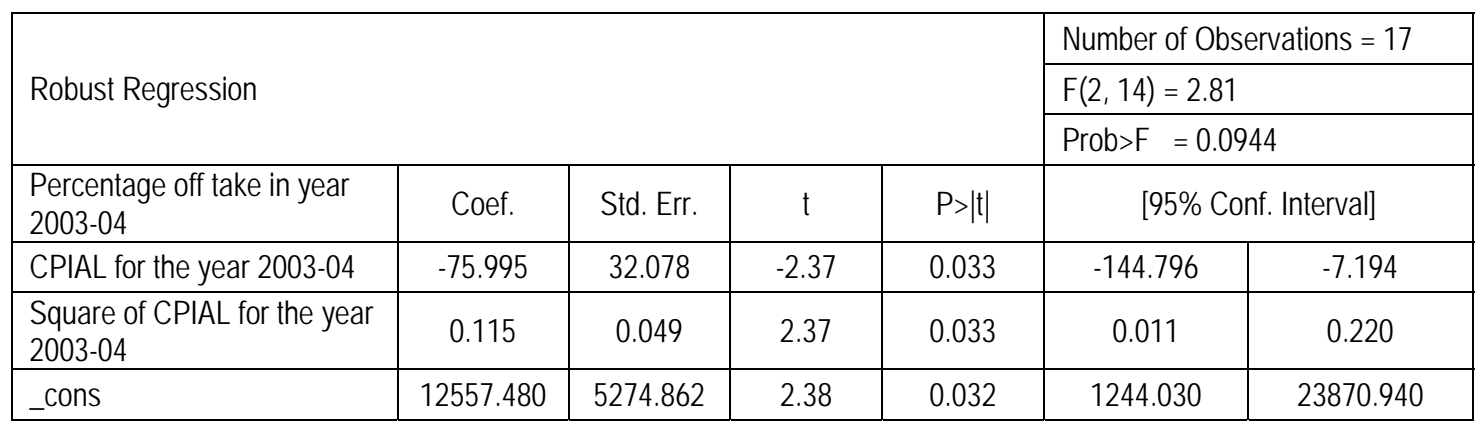

